wich" technique. In no case were circulating P.C.A. detected postoperatively that had not been found in the preoperative specimen. The incidence of P.C.A. was below the normal range for the age and sex of the patients, but 2 of $22(9 \%)$ patients with gastric cancer showed circulating P.C.A.

The failure to demonstrate circulating parietal-cell antibodies in serial specimens of serum taken from patients who had undergone gastric surgery does not support the hypothesis that autoimmunization is the result of damage to the gastric mucosa.

My thanks are due to Mr. T. J. Butler, who suggested this investigation; to Burroughs Wellcome, who kindly gave the fluorescein-labelled anti-human gammaglobulin used in this study; and particularly to Dr. W. J. Harrison for his interest, help, and constructive criticism, without which this work would never have been possible. I wish to acknowledge the financial assistance of the S,W. Regional Hospital Board Research Fund in supporting my work.

\section{REFERENCES}

Coghill, N. F., Doniach, D., Roitt, I. M., Mollin, D. L., and Williams, A. W. (1965). Gut, 6, 48.

Coghili, N. F., and Williams, A W. (1958). Proc. roy. Soc. Med., 51, 464.

Doniach, D., Roitt, I. M., and Taylor, K. B. (1963). Brit. med. F., 1, 1374.

Fisher, June Marion, Mackay, I. R., Taylor, K. B., and Berta Ungar (1967). Lancet, 1, 176.

Fisher, June Marion, and Taylor, K. B. (1967). Lancet, 1, 695

Irvine, W. J. (1963). Quart. F. exp. Physiol., 48, 427

Jenner, A. W. F. (1939). Acta med. scand., $102,529$.

Kleinsorge, H., Dornbusch, S., Jäger, D., and Jäger, L. (1957-8). Wiss. Z. Friedrich Schiller-Univ. Jena, 7, 455.

Krause, U. (1958). Acta chir. scand., 114, 341.

Kravetz, R. E., Van Noorden, S., and Spiro, H. M. (1967). Lancet, 1, 235.

Lees, F., and Grandiean, L. C. (1958). Arch. intern. Med., 101, 943.

Roitt, I. M., and Doniach, D. (1958). Lancet, 2,1027

Shiner, M., and Doniach, I. (1957). Gastroenterology, 32, 313

Taylor, K., B., Roitt, I. M., Doniach, D., Couchman, K. G., and Shapland, C. (1962). Brit. med. 7., 2, 1347.

Thompson, C. E. R. (1967), Personal communication.

Welbourn, R. B., Nelson, M. G., and Zacharias, F. J. (1956). Brit. F. Surg., 43, 422.

\title{
Childhood Splenomegaly in Uganda, and its Relation to Malaria
}

\author{
THERESE M. VANIER,* M.B., M.R.C.P. ; M. S. R. HUTT, $†$ M.D., F.R.C.P., F.C.PATH. \\ G. C. COOK, $\ddagger$ M.D., B.SC., M.R.C.P.
}

Brit. med. F., 1968, 2, 649-653

Splenomegaly of mild degree is common among children in Uganda and in many other tropical and subtropical countries. This may be transient and is usually due to malaria, but it can also be due to other infective illnesses (McGregor et al., 1956 ; Fawdry and Trowell, 1958 ; Edington, 1967). There is a group of children, however, who have a grosser degree of splenic enlargement of long duration in which investigations show no obvious cause. These cases have been called "idiopathic tropical splenomegaly" of childhood, and may be compared with the same syndrome in adults. Recent investigation of idiopathic tropical splenomegaly in Ugandan adults suggests that the majority of such cases are due to malarial infection, though whether this is an altered host response or an infection by a specific type of malaria is still uncertain (Gebbie et al., 1964 ; Marsden et al., 1965). The problem of gross splenomegaly in childhood in Uganda has not hitherto been investigated. This paper reports investigations on 32 children with idiopathic tropical splenomegaly.

\section{Patients and Methods}

Thirty-two children with "very big spleens" were investigated. Their spleens were enlarged to or below the umbilicus, and all had hepatomegaly. The children were aged 4 months to 10 years and belonged to 15 different tribes (Table I); most lived within 20 miles $(32 \mathrm{~km}$.), but some as far as 100 miles $(160 \mathrm{~km}$.) from the hospital. Those with the largest spleens and much cutaneous scarification had the longest histories of splenic enlargement (Fig. 1). In all cases a history of intermittent fever was obtained, but that is so common in Uganda that it is of little significance. There was no history of umbilical sepsis. Jaundice had been noted at some time in seven children, three of whom had sickle-cell disease. In one child severe kwashiorkor, bilateral corneal necrosis, and prolapse of the iris, probably due to vitamin-A deficiency, were present. One had marasmus at the time of admission, and Cases 7 , $12,16,19,23$, and 32 had a history or clinical picture suggesting mild or moderate malnutrition. Case 12 also had osteomyelitis.

* Clinical Haematologist, St. Thomas's Hospital, London S.E.1.

t Professor of Pathology, Makerere University College Medical School, Kampala, Uganda. The pathological aspects of the work were supported by a grant from W.H.O.

¥ Le turer in Medicine, Makerere University College Medical School, Kampala, Uganda. Present address: Department of Medicine, the Royal Free Hospital, London W.C.I.
Three measurements were made to record spleen size: (A) the distance from the xiphisternum to a horizontal line connecting the lowest level of the spleen to the midline, (B) from the midaxillary line to the most medial point of the spleen, and (C) from the costal margin at the nipple-line to the lowest point of the spleen. The sum of $\mathbf{A}$ and $\mathbf{B}$ was used in assessing change in size during follow-up studies. The liver was measured vertically from the right costal margin at the nipple-line to its lowest point.

Haematological investigations, were carried out in all cases by means of standard techniques (Dacie and Lewis, 1963). Thick and thin blood films were examined for malarial parasites on the day of admission, daily throughout the time in hospital (2-30 days, mean 5 days), and at each subsequent outpatient attendance. In 25 children further investigations included stool and urine examination, serum bilirubin, aspartate and alanine aminotransferase, alkaline

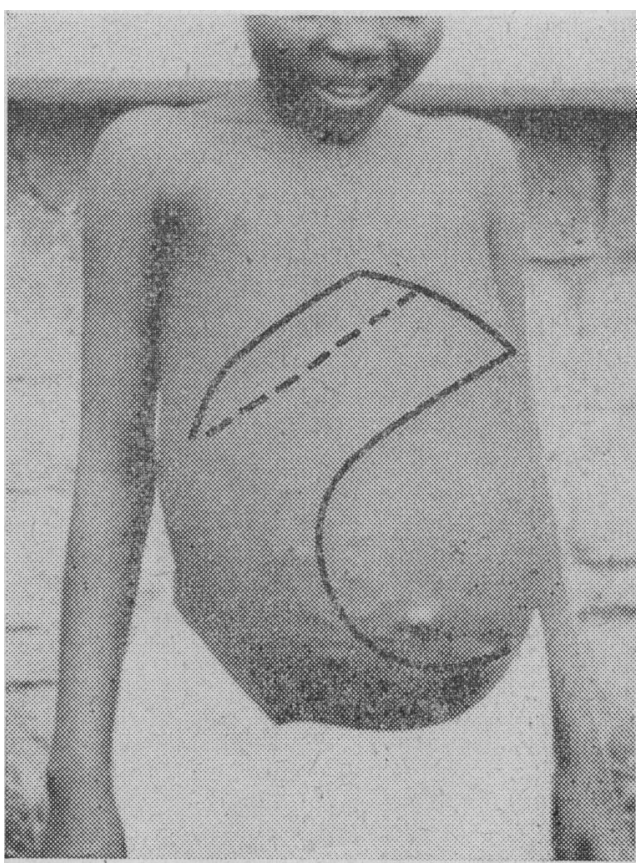

FIG. 1.-Case 32. Gross splenomegaly and cutaneous scarification. 
phosphatase, total proteins and electrophoresis, and malarial antibody titre (Voller, 1964), Plasmodium falciparum being used as antigen. Liver biopsy was performed under sedation and local anaesthesia in 24 of the children by an anterior subcostal approach, a 1.9-mm. Menghini (1958) needle being used. There were no complications. All biopsy specimens were processed as previously reported (Cook and Hutt, 1967) and were examined on several occasions by all of us. They were compared with biopsies from six European children who had not lived in the tropics (Cook and Hutt, 1967). One patient (Case 13) died shortly after admission, and - liver histology was examined from material obtained at necropsy. At the same time as the liver biopsies bone marrow from the iliac crest was obtained in 19 children.

Terminology.-The finding of idiopathic tropical splenomegaly and hepatic sinusoidal lymphocytosis in Ugandan adults has recently been referred to as "big spleen disease" (Hamilton et al., 1966, 1967). Such cases often have a very high fluorescent malarial antibody titre (Gebbie et al., 1964), absence of malarial pigment in liver biopsy specimens, excessive Kupffer cell hyperplasia, and a high incidence of $P$. malariae parasitaemia (Marsden et al., 1965). The term "tropical splenomegaly syndrome" has recently been suggested for these cases of gross splenomegaly seen in the tropics in which no definitive cause can be established (Brit. med. F., 1967), though the majority probably represent an unusual response to malarial infection.

Effect of Treatment.-Cases 25 and 32 were followed up for 20 months and 17 others for one to six months to attempt assessment of the short-term effect of malarial prophylaxis and cytotoxic agents. Antimalarials were given as: chloroquine tablets, therapeutically, $300 \mathrm{mg}$. (base) daily for three days to children over a year and $150 \mathrm{mg}$. for those under a year, and, prophylactically, $150 \mathrm{mg}$. weekly to children over a year and $75 \mathrm{mg}$. for those under a year. Primaquine was given for 10 days in a dose of $0.15 \mathrm{mg}$. (base)/lb./ day. Oral cyclophosphamide or azathioprine was given to two children on the supposition that this splenomegaly may have an immunological basis.

\section{Results}

Table I summarizes the clinical findings and diagnosis. The diagnosis of "active malaria" was based on hepatic sinusoidal pigment if liver biopsy specimens were obtained or on the presence of a heavy parasitaemia.

\section{Liver Histology}

When compared with liver biopsy specimens from the six European children none showed exactly similar histology.
Those with the most minor differences all had an increase in the size and number of Kupffer cells, a slight increase in sinusoidal lymphocytes, and a slight increase in portal infiltration that was insufficient to expand the portal areas (Cook and Hutt, 1967). In most, however, there were more gross changes, which are summarized in Table II. Case 27 had an advanced cirrhosis; in all others the normal liver architecture was preserved. In Case 23 there was a marked degree of variation in nuclear size in the parenchymal cells, and in this and in Case 3 there was marked nuclear vacuolation. Cases $8,11,27$, and 31 had an excess of fat in the parenchymal cells, which in Case 27 was accompanied by cirrhosis. In Cases 1, 2, 3, 17, and 26 iron was present in the parenchymal cells. Cases 12, 22, and 32 showed "stellate" fibrosis radiating from the portal areas. This was very pronounced in Case 12 . Case 2, 10, 22, and 31 had portal tract infiltration with lymphocytes and occasional eosinophils and plasma cells which expanded the portal areas.

In 14 specimens there was an excess of sinusoidal lymphocytes (Cook and Hutt, 1967), which was gross in Cases 5 and 30 (Table II). Kupffer cells showed an increase above the usual level for Ugandan children (Cook and Hutt, 1967) in all except Case 28. In Cases 30 and 31 the Kupffer cells contained free iron. Fifteen of the biopsy specimens contained malarial pigment in the Kupffer cells and/or the portal tracts. Granulomata were demonstrated in Cases 11, 16, 17, 24, and 29. In Cases 11 and 29 they were associated with schistosomal ova and in Case 17 with tuberculous caseation; Case 24 had a positive brucella agglutination; and in Case 16 they consisted of illdefined areas of infiltration associated with parenchymal cell necrosis (Cook and Hutt, 1967) and the cause is unknown. In Case 31 schistosomal granulomata were found in the necropsy specimen.

\section{Parasitology}

Table II summarizes the results of malarial parasitaemias and antibody titres. Malarial antibody titres were not related to gammaglobulin levels, age, or the presence of hepatic sinusoidal lymphocytosis.

In Case 29 Schistosoma mansoni was found in the stool. In 10 children hookworms (Necator americanus) were found, in three Ascaris lumbricoides, and in one Giardia lamblia.

\begin{tabular}{|c|c|c|c|c|c|c|c|}
\hline \multirow[b]{2}{*}{ Case No. } & \multirow[b]{2}{*}{ Age in Years } & \multirow[b]{2}{*}{ Sex } & \multirow[b]{2}{*}{ Tribe } & \multicolumn{2}{|c|}{ Spleen Size } & \multirow{2}{*}{$\begin{array}{c}\text { Liver Size } \\
\text { (cm. Below } \\
\text { Costal Margin) }\end{array}$} & \multirow[b]{2}{*}{ Diagnosis } \\
\hline & & & & 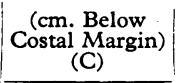 & $\begin{array}{c}\mathrm{A}+\mathrm{B}, \mathrm{cm} . \\
(\text { See Text) }\end{array}$ & & \\
\hline $\begin{array}{r}1 \\
2 \\
3 \\
4 \\
5 \\
6 \\
7 \\
8 \\
9 \\
10 \\
11 \\
12 \\
13 \\
14 \\
15 \\
16 \\
17 \\
18 \\
19 \\
20 \\
21 \\
22 \\
23 \\
24 \\
25 \\
26 \\
27 \\
28 \\
29 \\
30 \\
31 \\
32\end{array}$ & $\begin{array}{l}0 \cdot 3 \\
0.7 \\
0.7 \\
0.9 \\
1 \\
1 \cdot 4 \\
1.5 \\
2.5 \\
2 \\
2.5 \\
3 \\
3 \\
3 \\
3 \\
3 \\
4 \\
4 \\
4 \\
5 \\
6 \\
6 \\
7 \\
7 \\
7 \\
8 \\
8 \\
8 \\
8 \\
9 \\
9 \\
9 \\
10\end{array}$ & $\begin{array}{l}F \\
F \\
M \\
M \\
M \\
F \\
F \\
M \\
M \\
M \\
M \\
M \\
\mathcal{F} \\
M \\
F \\
F \\
F \\
M \\
F \\
M \\
F \\
M \\
M \\
M \\
F \\
F \\
M \\
F \\
F \\
F \\
M \\
F\end{array}$ & $\begin{array}{l}\text { Iru } \\
\text { Luya } \\
\text { Ganda } \\
\text { Ganda } \\
\text { Ganda } \\
\text { “aongo " } \\
\text { Madi } \\
\text { Luya } \\
\text { Ganda } \\
\text { Ganda } \\
\text { Acholi } \\
\text { Achoa } \\
\text { Zamia } \\
\text { Kamia } \\
\text { Kaawa } \\
\text { Ganda } \\
\text { Ganda } \\
\text { Ganda } \\
\text { Ganda } \\
\text { Ganda } \\
\text { Kakwa } \\
\text { Ganda } \\
\text { Iru } \\
\text { Ganda } \\
\text { Tutsi } \\
\text { Ganda } \\
\text { Ganda } \\
\text { Gisu } \\
\text { Ganda } \\
\text { Acholi } \\
\text { Soga } \\
\text { Sukuma } \\
\text { Hutu }\end{array}$ & $\begin{array}{r}11 \\
4 \\
8 \\
4 \\
8 \\
8 \\
7 \\
8 \\
5 \\
13 \\
15 \\
8 \\
8 \\
6 \\
9 \\
13 \\
14 \\
8 \\
7 \\
8 \\
7 \\
10 \\
8 \\
9 \\
18 \\
15 \\
7 \\
11 \\
7 \\
13 \\
8 \\
20\end{array}$ & $\begin{array}{l}26 \\
12 \\
22 \\
12 \\
24 \\
23 \\
20 \\
21 \\
15 \\
30 \\
31 \\
22 \\
19 \\
16 \\
16 \\
32 \\
31 \\
14 \\
28 \\
18 \\
18 \\
26 \\
16 \\
23 \\
41 \\
33 \\
18 \\
19 \\
17 \\
33 \\
24 \\
42\end{array}$ & $\begin{array}{l}3 \\
4 \\
2 \\
3 \\
2 \\
2 \\
4 \\
3 \\
4 \\
4 \\
6 \\
2 \\
7 \\
2 \\
4 \\
4 \\
4 \\
4 \\
4 \\
4 \\
2 \\
4 \\
2 \\
6 \\
3 \\
4 \\
7 \\
6 \\
4 \\
2 \\
4 \\
3\end{array}$ & $\begin{array}{l}\text { Active malaria } \\
\text { Active malaria; marasmus } \\
\text { Active malaria } \\
\text { Active malaria* } \\
\text { Sickle-cell disease } \\
\text { Active malaria } \\
\text { Active malaria } \\
\text { Active malaria } \\
\text { Active malaria; pulmonary tuberculosis* } \\
\text { Active malaria } \\
\text { Sickle-cell disease; schistosomiasis } \\
\text { Active malaria } \\
\text { Active malaria; bronchopneumonia } \\
\text { Acte leukaemia } \\
\text { Active malaria* } \\
\text { Active malaria; hepatic granuloma } \\
\text { Sickle-cell disease; miliary tuberculosis } \\
\text { Active malaria* } \\
\text { Active malaria } \\
\text { Active malaria* } \\
\text { Active malaria* } \\
\text { Reticulosis } \\
\text { Active malaria; pulmonary tuberculosi } \\
\text { Brucellosis } \\
\text { Active malaria } \\
\text { Sickle-cell disease } \\
\text { Cirrthosis; kwashiorkor } \\
\text { Sickle-cell disease } \\
\text { Active malaria; schistosomiasis } \\
\text { Sickle-cell disease } \\
\text { Schistosomiasis } \\
\text { Tropical splenomegaly syndrome }\end{array}$ \\
\hline
\end{tabular}




\section{Haematology}

Tables II and III summarize the results. There was a significant inverse relationship between haemoglobin level and spleen size $(r,-0.606 ; P<0.05)$. Cases 16,25 , and 32 , who had the biggest spleens (Case 25 also had folic acid deficiency), and Case 24, who had brucellosis, had white cell counts of 4,000/ cu. mm. or less. The lowest platelet counts were associated with the largest spleens, but in Case 1 the initial count of $17,000 / \mathrm{cu}$. mm. rose as the malarial parasitaemia cleared on treatment. Neither white cell count nor platelet count showed a significant relation to spleen size. A reticulocytosis was present in all except Cases 14, 23, and 25; the two highest levels were in children with sickle-cell disease. Macrocytes were present in Case 25. The six cases of sickle-cell disease showed Howell-Jolly bodies, Heinz bodies, target cells, and spherocytes. The direct Coombs test was negative in all.

Table III gives results of bone marrow examinations. All except Case 25, who had a megaloblastic marrow, showed marked normoblastic hyperplasia. Only two had high lymphocyte levels (Smith, 1966); the highest was in a child with pulmonary tuberculosis. Sideroblasts and "free" iron were absent or greatly reduced except in children with sickle-cell disease who had had several blood transfusions.

\section{Other Investigations}

Serum bilirubin was raised in Cases 12, 22, and 27, and in the six with sickle-cell disease. Aspartate and alanine aminotransferases were raised in Cases 12 and 27 . Alkaline phosphatase levels were between 5 and 18 King-Armstrong units except in Case 1 (40 units) (normal range 5-20 K.A. units (Nelson, 1964)). The total gammaglobulin was raised above normal levels for European children in most (Nelson, 1964) (Table II). No abnormality was found on routine urine microscopy.

\section{Results of Treatment}

Fig. 2 summarizes the changes in spleen size in relation to the species of malarial parasite and prophylaxis. Of the 17 children followed for up to six months only 12 had active malaria; one did not have a parasitaemia. Figs. 3 and 4 summarize the findings in the two cases followed for 20 months.

\section{Discussion}

All the children had gross splenomegaly. While splenic enlargement is common in children living in areas of holoendemic malaria, in only a few is it gross.

The diagnosis of "active malaria" was made in 20 of the 32 patients. In 14 this was based on liver biopsy appearances; in three children under 1 year of age pigment was present in large amounts. All showed Kupffer cell proliferation, and in nine there was also lymphocytic infiltration of the hepatic

TABLB III.-Results of Bone-marrow Examination

\begin{tabular}{|c|c|c|c|c|}
\hline \multirow[b]{2}{*}{ Case No. } & \multirow{2}{*}{$\begin{array}{c}\text { Myeloid/ } \\
\text { Erythroid } \\
\text { Ratio }\end{array}$} & \multirow[b]{2}{*}{$\begin{array}{c}\% \\
\text { Lymphocytes }\end{array}$} & \multicolumn{2}{|c|}{ Iron } \\
\hline & & & $\begin{array}{l}\text { Sideroblasts } \\
\text { (\% Nucleated } \\
\text { Red Cells) }\end{array}$ & "Free" \\
\hline $\begin{array}{r}1 \\
2 \\
3 \\
4 \\
5 \\
6 \\
7 \\
8 \\
9 \\
10 \\
11 \\
12 \\
13 \\
14 \\
15 \\
16 \\
17 \\
18 \\
19 \\
20 \\
21 \\
22 \\
23 \\
24 \\
25 \\
26 \\
27 \\
28 \\
29 \\
30 \\
31 \\
32\end{array}$ & $\begin{array}{c}1: 3 \\
1: 1 \\
1 \cdot 5 \\
= \\
\bar{Z} \\
1: 1 \cdot 2 \\
1 \cdot 3: 1 \\
1: 1 \cdot 8 \\
1: 2 \\
- \\
\overline{1: 3} \\
1: 2 \\
1: 1 \cdot 1 \\
\bar{Z} \\
1: 2 \\
1: 1 \\
1 \cdot 8: 1 \\
1: 4^{*} \\
1: 3 \\
\bar{Z} \\
1 \cdot 5: 1 \\
1: 4 \\
1: 1 \\
1: 4\end{array}$ & $\begin{array}{c}14 \\
10 \\
5 \\
= \\
= \\
\overline{10} \\
\frac{1}{35} \\
15 \\
13 \\
\frac{1}{\text { Acute leuk }} \\
0 \cdot 5 \\
21 \\
\overline{10} \\
\frac{}{7} \\
15 \\
43 \\
6 \\
1 \\
10 \\
\frac{-}{7} \\
8 \\
2 \\
2\end{array}$ & $\begin{array}{l}12 \\
\text { Neg. } \\
\text { Neg. } \\
= \\
= \\
\overline{-} \\
\text { Neg. } \\
\overline{\text { Neg. }} \\
\text { Neg. } \\
\text { Neg. } \\
\overline{-} \text { aemia } \\
\overline{\text { Neg. }} \\
\frac{44}{\bar{N}} \\
\text { Neg. } \\
\overline{-} \\
\text { Neg. } \\
\text { Neg. } \\
\text { Neg. } \\
30 \\
\overline{3} \\
\bar{N} \text { eg. } \\
36 \\
10 \\
4\end{array}$ & 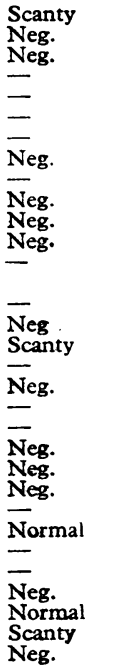 \\
\hline
\end{tabular}

* Megaloblastic erythropoiesis.

TABLE II.-Results of Laboratory Investigations and Liver Hisiology in the Children Studied

\begin{tabular}{|c|c|c|c|c|c|c|c|c|c|c|c|c|c|}
\hline \multirow{3}{*}{$\begin{array}{l}\text { Case } \\
\text { No. }\end{array}$} & \multirow{3}{*}{$\begin{array}{c}\text { Haemo- } \\
\text { globin } \\
\text { (g. } / 100 \mathrm{ml} .)\end{array}$} & \multirow{3}{*}{$\begin{array}{l}\text { Reticulo- } \\
\text { cytes (\%) }\end{array}$} & \multirow{3}{*}{$\begin{array}{c}\text { Total } \\
\text { White } \\
\text { Cell } \\
\text { Count } \\
\text { per } \\
\text { cu. mm. } \\
\times 10^{3}\end{array}$} & \multirow{3}{*}{$\begin{array}{c}\text { Platelet } \\
\text { Count } \\
\text { per } \\
\text { cu. mm. m. } \\
\times 10^{3}\end{array}$} & \multirow{3}{*}{$\begin{array}{l}\text { Haemo- } \\
\text { globin } \\
\text { Electro- } \\
\text { phoresis }\end{array}$} & \multirow{3}{*}{$\begin{array}{c}\text { Total } \\
\text { Serum } \\
\text { Proteins } \\
\text { (g.l } \\
100 \mathrm{ml} .)\end{array}$} & \multirow{3}{*}{$\begin{array}{c}\gamma \text {-globulin } \\
(\mathrm{g} . \mathrm{l} \\
100 \mathrm{ml} .)\end{array}$} & \multirow{3}{*}{$\begin{array}{c}\text { Malarial } \\
\text { Parasitest }\end{array}$} & \multirow{3}{*}{$\begin{array}{c}\text { Malarial } \\
\text { Antibody } \\
\text { Titre } \\
\text { (Control } \\
\text { Serum } \\
<1: 100 \text { ) }\end{array}$} & \multicolumn{4}{|c|}{ Liver Histology } \\
\hline & & & & & & & & & & \multirow{2}{*}{$\begin{array}{l}\text { Excessive } \\
\text { Sinusoidal } \\
\text { Lympho- } \\
\text { cytes } \neq\end{array}$} & \multirow{2}{*}{\begin{tabular}{|c} 
Excessive \\
Kupffer \\
Cell \\
Prolifer- \\
ation $\neq$
\end{tabular}} & \multicolumn{2}{|c|}{$\begin{array}{c}\text { Malarial } \\
\text { Pigment }\end{array}$} \\
\hline & & & & & & & & & & & & Sinusoids & $\begin{array}{l}\text { Portal } \\
\text { Tracts }\end{array}$ \\
\hline $\begin{array}{r}1 \\
2 \\
3 \\
4 \\
5 \\
6 \\
7 \\
8 \\
9 \\
10 \\
11 \\
12 \\
13 \\
14\end{array}$ & $\begin{array}{r}3.6 \\
10.2 \\
4.2 \\
8.7 \\
7.8 \\
10.8 \\
6.3 \\
8.5 \\
6.2 \\
7.7 \\
4.4 \\
7.7 \\
7.9\end{array}$ & $\begin{array}{c}12 \\
9 \\
17 \\
10 \\
15 \\
7 \cdot 2 \\
12 \\
5 \cdot 2 \\
3 \\
5 \cdot 3 \\
17 \\
15 \\
10\end{array}$ & $\begin{array}{c}6 \\
21 \\
5 \\
10 \\
10 \\
6 \\
13 \\
7 \\
8 \cdot 1 \\
5 \\
12 \\
18 \\
12\end{array}$ & $\begin{array}{r}17 \\
200 \\
100 \\
150 \\
90 \\
77 \\
220 \\
95 \\
152 \\
81 \\
210 \\
360 \\
102\end{array}$ & $\begin{array}{l}\mathrm{AA} \\
\mathrm{AA} \\
\mathrm{AA} \\
\mathrm{AA} \\
\mathrm{SS} \\
\mathrm{AA} \\
\mathrm{AA} \\
\mathrm{AA} \\
\mathrm{AA} \\
\mathrm{AA} \\
\mathrm{SA} \\
\mathrm{AA} \\
\mathrm{AA}\end{array}$ & $\begin{array}{r}6.1 \\
5.9 \\
\text { N.D. } \\
\text { N.D. } \\
7.3 \\
7.2 \\
\text { N.D. } \\
7.0 \\
\text { N.D. } \\
7.4 \\
7.1 \\
6.7 \\
6.5\end{array}$ & $\begin{array}{c}1.4 \\
1.3 \\
\text { N.D. } \\
\text { N.D. } \\
2.3 \\
2.7 \\
\text { N.D. } \\
1.8 \\
\text { N.D. } \\
2.2 \\
2.3 \\
2.1 \\
1.2\end{array}$ & $\begin{array}{l}\text { of } \\
f \\
\text { f } m \\
f \\
-f m \\
f m \\
- \\
f \\
m \\
- \\
f \\
f\end{array}$ & $\begin{array}{r}100 \\
200 \\
800 \\
N . D . \\
1,600 \\
400 \\
1,600 \\
400 \\
\text { N.D. } \\
200 \\
<100 \\
\text { N.D. } \\
800\end{array}$ & $\begin{array}{c}+ \\
+ \\
+ \\
\text { N.D. } \\
++ \\
0 \\
0 \\
0 \\
0 . D . \\
\text { N.D. } \\
+ \\
+ \\
0\end{array}$ & $\begin{array}{c}+ \\
+ \\
+ \\
\text { N.D. } \\
+ \\
+ \\
+ \\
+ \\
+ \\
\text { N.D. } \\
+ \\
+ \\
+\end{array}$ & $\begin{array}{c}+ \\
+ \\
+ \\
\text { N.D. } \\
+ \\
+ \\
+ \\
+ \\
\text { N.D. } \\
\pm \\
+ \\
+\end{array}$ & $\begin{array}{c}+ \\
+ \\
+ \\
\text { N.D. } \\
+ \\
+ \\
+ \\
+ \\
\text { N.D. } \\
\pm \\
\pm \\
+ \\
+\end{array}$ \\
\hline $\begin{array}{l}14 \\
15 \\
16 \\
17 \\
18 \\
19 \\
20 \\
21 \\
22 \\
23 \\
24 \\
25 \\
26 \\
27\end{array}$ & $\begin{array}{r}8.2 \\
8.5 \\
5.2 \\
9.9 \\
10.2 \\
7.0 \\
5.5 \\
10.0 \\
13.6 \\
11.2 \\
2.5 \\
6.3 \\
8.2\end{array}$ & $\begin{array}{c}\text { Acute } \\
4 \\
11 \\
38 \\
5 \\
6 \cdot 7 \\
14 \\
9 \\
17 \\
1 \\
4 \\
<1 \\
44 \\
15\end{array}$ & $\begin{array}{c}\text { emia } \\
7 \cdot 2 \\
3 \cdot 2 \\
9 \cdot 6 \\
6 \cdot 6 \\
6 \cdot 5^{*} \\
8 \\
6 \\
10 \\
11 \\
2 \\
3 \\
9 \\
4 \cdot 3\end{array}$ & $\begin{array}{r}130 \\
85 \\
107 \\
152 \\
70 \\
200 \\
140 \\
200 \\
200 \\
120 \\
69 \\
118 \\
110\end{array}$ & $\begin{array}{l}\mathrm{AA} \\
\mathrm{AA} \\
\mathrm{AA} \\
\mathrm{SA} \\
\mathrm{AA} \\
\mathrm{AA} \\
\mathrm{AA} \\
\mathrm{AA} \\
\mathrm{AA} \\
\mathrm{AA} \\
\mathrm{AA} \\
\mathrm{AA} \\
\mathrm{SA} \\
\mathrm{AA}\end{array}$ & $\begin{array}{c}\text { N.D. } \\
\text { N.D. } \\
8.3 \\
8.8 \\
\text { N.D. } \\
6.8 \\
\text { N.D. } \\
\text { N.D. } \\
\text { 9.1 } \\
7.1 \\
7.3 \\
6.9 \\
8.6 \\
7.8\end{array}$ & $\begin{array}{c}\text { N.D. } \\
\text { N.D. } \\
2.4 \\
2.7 \\
\text { N.D. } \\
2.0 \\
\text { N.D. } \\
\text { N.D. } \\
3.8 \\
1.8 \\
2.0 \\
2.1 \\
2.7 \\
3.1\end{array}$ & $\begin{array}{l}\bar{f} \\
- \\
f \\
\text { mf } \\
f \\
f \\
= \\
\bar{m} \\
=\end{array}$ & $\begin{array}{r}100 \\
\text { N.D. } \\
400 \\
>1,600 \\
\text { N.D. } \\
800 \\
\text { N.D. } \\
\text { N.D. } \\
800 \\
<100 \\
100 \\
200 \\
1,600 \\
400\end{array}$ & $\begin{array}{c}\text { N.D. } \\
\text { N.D. } \\
+ \\
+ \\
\text { N.D. } \\
+ \\
\text { N.D. } \\
\text { N.D. } \\
0 \\
+ \\
0 \\
+ \\
0 \\
\text { Not }\end{array}$ & $\begin{array}{c}\text { N.D. } \\
\text { N.D. } \\
+ \\
+ \\
\text { N.D. } \\
+ \\
\text { N.D. } \\
\text { N.D. } \\
+ \\
+ \\
+ \\
+ \\
+ \\
\text { Not }\end{array}$ & $\begin{array}{c}\text { N.D. } \\
\text { N.D. } \\
\pm \\
\text { N.D. } \\
+ \\
\text { N.D. } \\
\text { N.D. } \\
\pm \\
\pm \\
\pm \\
\pm \\
=\end{array}$ & $\begin{array}{c}\text { N.D. } \\
\text { N.D. } \\
\pm \\
\text { N.D. } \\
+ \\
\text { N.D. } \\
\text { N.D. } \\
+ \\
\pm \\
\pm \\
= \\
=\end{array}$ \\
\hline $\begin{array}{l}28 \\
29 \\
30 \\
31 \\
32\end{array}$ & $\begin{array}{r}9.0 \\
10.5 \\
3.5 \\
7.7 \\
6.0\end{array}$ & $\begin{array}{l}12 \cdot 8 \\
4 \\
31 \\
5 \\
25\end{array}$ & $\begin{array}{c}10 * \\
3 \cdot 8 \\
20 \\
4 \\
2 \cdot 8\end{array}$ & $\begin{array}{r}70 \\
110 \\
67 \\
25 \\
54\end{array}$ & $\begin{array}{l}\text { SS } \\
\text { AA } \\
\text { SS } \\
\text { AA } \\
\text { AA }\end{array}$ & $\begin{array}{l}6 \cdot 8 \\
9 \cdot 1 \\
8 \cdot 2 \\
5 \cdot 6 \\
6 \cdot 3\end{array}$ & $\begin{array}{r}2.0 \\
4.5 \\
2.6 \\
\text { N.D. } \\
1.7\end{array}$ & $\begin{array}{l}\bar{f} \\
\bar{m}\end{array}$ & $\begin{array}{r}1,600 \\
1,600 \\
<100 \\
200 \\
400\end{array}$ & $\begin{array}{c}0 \\
0 \\
++ \\
0 \\
+\end{array}$ & $\begin{array}{l}0 \\
+ \\
+ \\
+ \\
+\end{array}$ & $\begin{array}{l}\overline{ \pm} \\
\bar{z}\end{array}$ & $\begin{array}{l} \pm \\
\bar{I}\end{array}$ \\
\hline
\end{tabular}


sinusoids. In 11 cases malarial parasites were also present: $P$. falciparum in five, $P$. falciparum and $P$. ovale in one, $P$. falciparum and $P$. malariae in three, and $P$. malariae in two. One also had pulmonary tuberculosis and one had bronchopneumonia. Two others had granulomata, in one schistosomal. These non-malarious conditions were presumably not a significant cause of the gross splenomegaly. Six of the children were followed for one to six months, and, despite antimalarial treatment in all and prophylaxis in four, they showed little change in spleen or liver size (Fig. 2). In six other children the diagnosis of active malaria was based on parasitaemia and the clinical response to antimalarial treatment. In five of these treatment and prophylaxis with chloroquine rendered the spleen impalpable, and the liver also regressed within one to two weeks (Fig. 2). Acute malaria in monkeys has been shown to produce portal venous vasoconstriction and a rise in portal venous pressure (Skirrow et al., 1964); this may be a non-specific vascular reaction to shock. If such a mechanism plays a part in the transient splenomegaly of acute malaria in children it might have contributed to the rapid regression in size of the spleen and liver in these cases. The mean initial size of the spleen

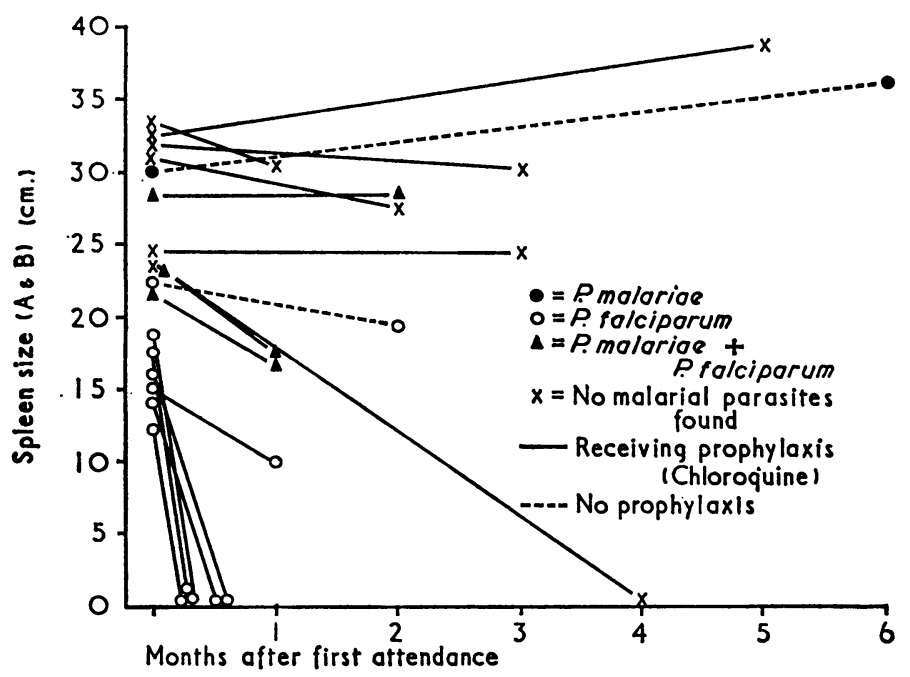

FIG. 2.-Change in spleen size $(A+B)$ (see tert) in 17 children during follow-up periods of up to six months.

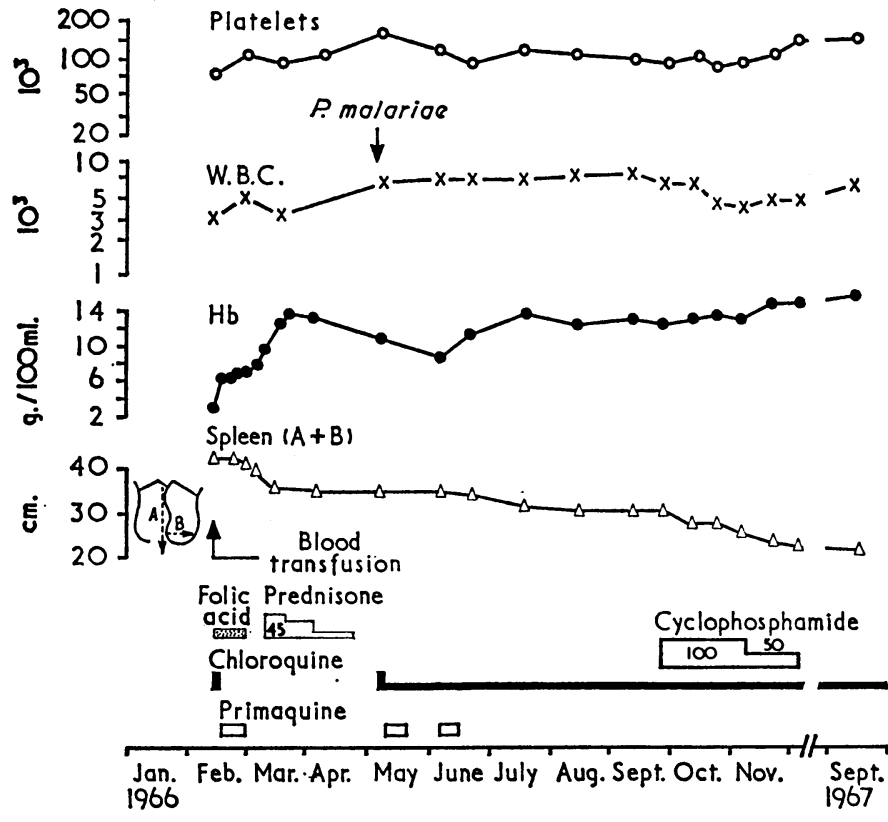

FIG. 3.-Change in spleen size and haematological findings in Case 25 with $P$. malariae infestation during the follow-up period of 20 months. in the latter group who responded to antimalarials was $15.5 \mathrm{~cm}$. $(A+B)$; this was less than in the group who did not respond $(28.0 \mathrm{~cm}$. $(\mathrm{A}+\mathrm{B}))$. The mean ages were, however, comparable (3.7 and 3.5 years). The persistent hepatosplenomegaly in the children who did not respond to antimalarial treatment was presumably a result of reticuloendothelial hyperplasia. The Kupffer cell hyperplasia and lymphocytic infiltration were a very marked feature in contrast with another series of children who had recovered from kwashiorkor, most of whom had malarial pigment but only a few had splenomegaly (Cook and Hutt, 1967). It has been suggested that in the adult these hepatic histological changes represent an altered host response to malarial infection by $P$. malariae (Marsden et al., 1965). In this series persistent splenomegaly was associated with $P$. malariae in five children, whereas transient splenomegaly was associated only with $P$. falciparum. The fact that $P$. malariae was found only after a six-month follow-up in Case 32 illustrates the difficulty in assessing its role. $P$. falciparum was found much more often under the age of 5 (11 out of 18 cases) than in the older group (4 out of 14 cases).

Only one child had hepatic sinusoidal lymphocytosis, Kupffer cell hyperplasia, $P$. malariae parasitaemia, and no malarial pigment ; the malarial antibody titre was $1: 400$. Her case simulates the tropical splenomegaly syndrome in adults (Gebbie et al., 1964 ; Marsden et al., 1965). It is possible that in children an "abnormal response" to malaria occurs at a time when malarial infection is more frequent, recent, and severe than in the adult. This would account for the presence of pigment associated with other histological features of the tropical splenomegaly syndrome.

Six children in this series had sickle-cell disease. Splenomegaly is unusual in this condition outside tropical areas (Diggs, 1965); gross splenomegaly associated with sickle-cell disease is very unusual in Kampala (Vanier, 1967). Another cause for the gross splenomegaly in these six children should thus be considered. One child also had miliary tuberculosis and another schistosomiasis, but it is unlikely that these diseases were significant. All except one had Kupffer cell hyperplasia, and in four there was hepatic sinusoidal lymphocytosis. None had malarial pigment. Four of the six had malarial antibody titres of $1: 1,600$ or more, and none had a malarial parasitaemia. These patients therefore had most of the features of the tropical splenomegaly syndrome as seen in adults. It seems probable that haemoglobin $S$ protects against severe $P$. falciparum infections, though the mechanism is not clear. It may

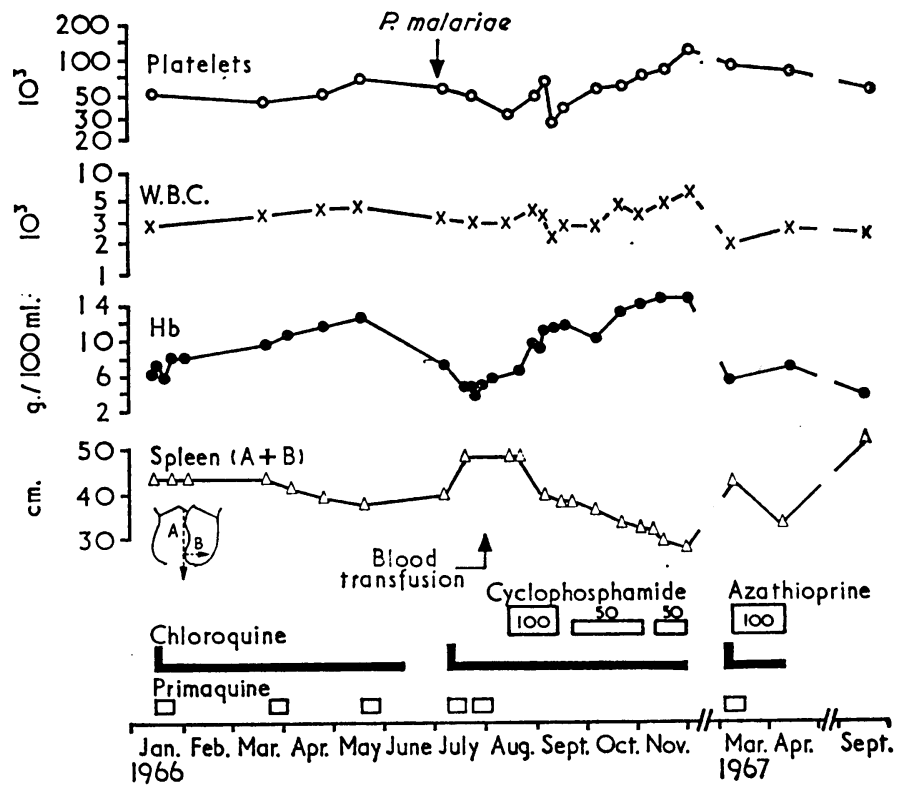

Fig. 4.-Change in spleen size and haematological findings in Case 32 with $P$ malariae infestation during the follow-up period of 20 months. 
not, however, protect against the exoerythrocytic cycle which may, we believe, be the cause of hepatic sinusoidal infiltration. The development of malarial antibodies may coexist with the rapid destruction of early schizonts in sickled red cells adherent to peripheral capillaries, which would prevent the rapid multiplication of parasites and the severe manifestations of $P$. falciparum malaria (Miller et al., 1956 ; Neel, 1962).

Hepatomegaly was a consistent finding in this series; it was usually slight or moderate in degree, but was pronounced in the cases with cirrhosis and brucellosis and in two with sicklecell disease. Hepatomegaly is well recognized as a sequel to malarial infection (Walters and McGregor, 1960), and it is of interest that hepatic and splenic regression occurred in five children with $P$. falciparum infections who were treated with chloroquine.

\section{Prophylaxis and Treatment}

Treatment and prophylaxis of malaria with proguanil have been reported to reduce spleen size in some cases of the tropical splenomegaly syndrome in adults (Hamilton et al., 1967 ; Watson Williams et al., 1967). In most cases of the present series the follow-up was inadequate. Chloroquine prophylaxis failed to reduce spleen size in the majority, though the patients felt better, had no attacks of fever, and maintained normal haemoglobin levels with only a mild reticulocytosis. The effect of proguanil on the pre-erythrocytic cycle may be important in preventing repeated antigenic stimulation rather than suppression of the erythrocytic phase. Spleen size was rapidly reduced by cytotoxic agents, though this change was discontinued as soon as the drug was stopped. Treatment with cytotoxic agents must be closely supervised, and this is impossible in most tropical areas.

Hamilton et al. (1967) have studied the effects of splenectomy in adults, and the danger of overwhelming infection after splenectomy in children in non-tropical areas has recently been clarified (Eraklis et al., 1967); the overall mortality under the age of 5 years in that study was more than twice that in older children. Fatalities from $P$. falciparum infection have been reported after splenectomy in adults (Watson Williams et al., 1967), and before considering this measure in children in the tropics long-term malaria prophylaxis with proguanil should be used in an attempt to reduce spleen size.

\section{Summary}

Thirty-two African children in Uganda have been investigated on account of gross splenomegaly. They were consecutive referrals to one of us (T.M. V.). Haematological investigations were done in all cases, and in 25 of them examination of liver histology was also carried out. A diagnosis of active malaria was made in 20 children on liver biopsy and haematological and parasitological evidence. One other child also had evidence of malaria, including parasitaemia, but no malarial pigment in the liver. Six children had homozygous sickle-cell disease, four of them with a greatly raised fluorescent malarial antibody, but all without malarial pigment in the liver. Evidence is presented which suggests that malaria is probably the cause of the gross splenomegaly in all of these children, and in many its cause and pathogenesis may be similar to that in Ugandan adults with splenomegaly and hepatic sinusoidal lymphocytosis. It is suggested that such findings in sickle-cell disease are compatible with the knowledge that haemoglobin $S$ confers protection from severe $P$. falciparum infection.

Nineteen of the children were followed up for from 1 to 20 months. In five splenomegaly regressed completely while they were on antimalarial treatment, and in a further two oral cytotoxic agents brought a decrease in spleen size.

One child had an advanced cirrhosis, one had acute leukaemia, and one had a reticulosis. In two who also had brucellosis and schistosomiasis, respectively, the cause of the splenomegaly was not satisfactorily explained.

It seems likely that in Uganda malaria is by far the most common cause of gross splenomegaly in children, though other causes should always be excluded.

We are grateful to Dr. R. Knight, Dr. N. J. Mody, Miss H. Senkatuka, Dr. N. E. Wilks, and Dr. D. Wykoff for help in this study. One of us (T.M. V.) was in receipt of a grant from the St. Thomas's Hospital Endowment Fund during a period of secondment from the Department of Haematology, St. Thomas's Hospital, London S.E.1.

\section{REFERENCES}

Brit. med. f., 1967, 4, 614.

Cook, G. C., and Hutt, M. S. R. (1967). Brit. med. F., 3, 454

Dacie, J. V., and Lewis, S. M. (1963). Practical Haematology, 3rd ed. London.

Diggs, L. W. (1965). Amer. F. clin. Path., 44, 1.

Edington, G. M. (1967). Brit. med. f., 1, 715.

Eraklis, A. J., Kevy, S. V., Diamond, L. K., and Gross, R. E. (1967). New Engl. f. Med., 276, 1225.

Fawdry, A. L., and Trowell, H. C. (1958). In H. C. Trowell and D. B. Jelliffe's Diseases of Children in the Subtropics and Tropics, p. 511. London.

Gebbie, D. A. M., Hamilton, P. J. S., Hutt, M. S. R., Marsden, P. D., Voller, A., and Wilks, N. E. (1964). Lancet, $2,392$.

Hamilton, P. J. S., Gebbie, D. A. M., Hutt, M. S. R., Lothe, F., and Wilks, N. E. (1966). Brit. med. Y., 2, 548.

Hamilton, P. J. S., Richmond, J., Donaldson, G. W. K., Williams, R., Hutt, M. S. R., and Lugumba, V. (1967). Brit. med. Y., 3, 823.

McGregor, I. A., Gilles, H. M., Walters, J. H., and Davies, A. H. (1956). Brit. med. f., 2, 686.

Marsden, P. D., et. al. (1965). Brit. med. 7., 1, 89.

Menghini, G. (1958). Gastroenterology, 35, 190.

Miller, M. J., Neel, J. V., and Livingstone, F. B. (1956). Trans. roy. Soc. trop. Med. Hyg., 50, 294.

Neel, J. V. (1962). In Methodology in Human Genetics, edited by W. J. Burdette, p. 198. San Francisco.

Nelson, W. E. (1964). Textbook of Paediatrics, 8th ed. London.

Skarrow, M. B., Chongsuphajaisiddhi, T., and Maegraith, B. G. (1964). Ann. trop. Med. Parasit., 58, 502.

Smith, C. H. (1966). Blood Diseases of Infancy and Childhood, 2nd ed.

Vanier, T. M. (1967). Personal observation.

Voller, A. (1964). Bull. Wld Hlth Org., 30, 343.

Walters, J. H., and McGregor, I. A. (1960). Trans. roy. Soc. trop. Med. Hyg., 54, 135.

Watson-Williams, E. J., Allan, N. C., and Fleming, A. F. (1967). Brit. 